\title{
Women, Polygyny and Economy: An Analysis on the Pre- Colonial Naga Society of North East India with Special Reference to the Lotha Nagas
}

\author{
Rosanna Kikon \\ Research Scholar, Department of History, Assam University, Diphu Campus, Diphu, Karbi Anglong, 782462, \\ Assam, India
}

\begin{abstract}
The aim of this study is to bring to light the contributions of women in the social milieu of the headhunting Naga society. The anarchical state of the country had rendered it necessary for Naga men to be always ready for an assault consequently the main bulk of work, of sustaining life, fell upon women. Polygyny was an added advantage for man as he could boast of enough supply of labour in his wives and children thereby enhancing his wealth. Considering the amount of labour women put into for the continuance of the tribe and to the economic advancement of the husbands, it could have earned her a place in the society but this was not so. Tradition and customs of the tribe favoured men and women's contributions were overshadowed by men's achievements.
\end{abstract}

Keywords- headhunting, polygyny, labour, tradition, patriarchal

\section{INTRODUCTION}

The Nagas are the indigenous people belonging to the state of Nagaland in the North Eastern part of India. The state of Nagaland is bounded by Assam in the west, Myanmar on the east, Manipur in the south and Arunachal Pradesh and part of Assam on the north. It lies between $25^{\circ} 6^{\prime}$ and 27 $7^{\circ}$ northern latitudes and between $93^{\circ} 20^{\prime}$ and $95^{\circ} 15^{\prime}$ eastern longitudes. The State has an area of 16,579 sq. Km (which constitutes $0.5 \%$ of the country's geographical area) with a population of 19,88,636 ( $0.2 \%$ of the country's population) as per 2001 Census (HDR, Nagaland, 2004, 4). For centuries, the Naga tribes inhabited this region independent of each other; each distinct in itself by language, customs and costumes. It was only under the colonial rule that the various tribes were conglomerated into a unit. Presently, they are known by the generic name Naga, composed of various tribes, of which, Angami, Ao, Chakhesang, Chang, Khiamnungkham, Konyak, Lotha, Pochury, Rengma, Sema, Sangtam, Yinchungru, Zeliang are some of the major tribes. The Lotha Naga tribe belong to Wokha district, which is located at the latitude of $26^{\circ} 8^{\prime}$ North and longitude of $94^{\circ} 18^{\prime}$ East with a geographical area of 1628 square kilometres constituting 9.82 percent of the state's geographical area. The district has a population of $1,66,343$ with a male population of 84,505 and 81,838 female population and has a sex ratio of 968 (HDR, WD, 2013, 7-9).

Historically, all Nagas were head-hunters and it was the ambition of every Naga to take a head not only for the magical benefits he conferred on his village but because it was only when a man could boast of having taken a head was he considered man enough to have a voice in the society. The Nagas lived independent of each other with the village as the political unit of the society. The patriarchal nature of the society emphasised on paternal lineage hence men directed the political, economic and cultural life. It is to be observed that though the Lothas were democratic in their choice of leaders, often than not, chieftainship was hereditary in the family of the man who originally founded the village, but did not at all necessarily pass from father to son. The Lotha chief, ekhüng, was assisted by a council of elders divided into two classes called tongti, the upper division and chochang, the lower division (Mills, 1980, 97). The selection of these administrators was done by an electorate college formed of adult males. Women were not a part of this political set up of the tribe; they were not even allowed to be anywhere near such meetings. The bachelor's house, chümpo, played an important part in the social life of the Lothas. The bachelor houses served as guard-houses, centres of education, and of activities during festivals and religious ceremonies. Herein, the young men were prepared for their tasks and responsibilities in life; they were taught the art of village administration, warfare, customary and traditional practices, cultivation, seasons, hunting, fishing, songs and dances, and handicrafts (Godden, 1897, 180). In the Lotha chümpo, raids were planned and discussed, and to it all heads taken were first brought. The bachelors' house was considered as sacred and women were not allowed to set foot in it or go anywhere near it. The crowning glory of a headhunter was the giving of the Feast of Merit. The Feasts were held in esteem for the privileges it brought to the donor- honour both then and after death and, he and his wife gained the right to wear special cloths. He was also entitled to embellish his house with carved posts and beams. No matter how rich a 
man was, he could win the right to these cloths and carvings only by giving the feasts (Mills, 1935, 134). It was only when one had given feasts that he got the right to erect stones commemorating his achievement. The religion of the Naga tribes has generally been assumed to be animism. The priest of the village, called pvïthi, initiated all ceremonies concerned with the welfare of the whole community (Mills, 1980, 121). Essentially, a man free of physical and moral blemish from the priestly clan was chosen. He was assisted by his assistant in performing all the ceremonies of the village. No woman was designated as a priestess but the office of the dreamer was normally held by a woman. She was the mediator between the souls of the dead and the living relatives (Murry, 2003, 6). The basis of Naga economy was agriculture and land formed the essential means of production. Land was collectively owned by the clan and all its members were allowed to cultivate it according to the rules of assignment of plots of land to each household. Patriarchal family structure rested on men's control of all property i.e., land, inherited exclusively by the male heirs.

\section{II.}

\section{LITERATURE REVIEW}

The early British ethnographic records and journals, Census Reports and monographs of anthropologists are the first known sources of information which serves as historical material towards the study of the Nagas. John Butler's Travels and Adventures in the Province of Assam (1855), A Glimpse of Assam by Sarah R Ward (1884) and T. Athol Joyce \& N.W. Thomas, ed., Women of All Nations (1915) provide descriptions of the traditional Naga life. The works of Mary Mead, Clark, A Corner in India (1907) and Elizabeth Vickland, ed., Women of Assam (1928) are sources highlighting Naga women's activities from the missionary point of view. The Angami Nagas by J.H. Hutton (1921; 2003), gives us information of the Angami society and also made a brief mention of the Lotha customs. The monograph of J. P. Mills, The Lotha Nagas (1922; 1980) is the only accomplished work on the Lotha society providing information on the social life, customs and religious beliefs of the tribe. Other works of importance giving us insight into the Naga way of life are J.H. Hutton's The Sema Nagas (1968); The Ao Nagas by J.P. Mills (1926); W.C. Smith's The Ao Naga Tribe of Assam (1925); J.H. Hutton's The Significance of Headhunting in Assam (JRAI, Vol. 58, July-December, 1928); Ursula Bower's The Naga Path (1950) and The Naked Nagas by C. Von Fürer Haimendorf (London, 1939). In all of these accounts the Naga women were seen as living in oppressed condition. Notes on the Wild Tribes Inhabiting the so called Naga Hills on the North East Frontier of India by R.G. Woodthorpe in two parts, is an ethnographic record of the Nagas (JRAI, Vol. XI, 1882, pp.56-73; pp.196-214). In Verrier Elwin's The Nagas in the Nineteenth Century (1969), the traditional life of the Nagas is seen through the eye-witness account of several writers. There is, therefore, very few available materials devoted to the study of traditional Lotha Naga women.

\section{OBJECTIVES}

The primary objective of the study is to highlight the role of women and their contribution to the economy of the society. It will bring to light how women, despite their enumerable contributions to the progress of the society, were excluded from the social, economic, religious and political spheres. It will also bring to light how polygyny profited men at the expense of the wives.

\section{METHODOLOGY}

The study is a historical analysis of the contribution of women to social and economic development of the Lotha Naga society. It is based on data collected through informal discussions with tradition holders and individuals on the role of women and practice of polygyny. To supplement the data the traditional customs, religious practices and the customary law of the tribe is taken into account. The study is further supplemented by colonial monographs, anthropological and ethnographic records and journals.

\section{POSITION OF WOMEN IN THE TRADITIONAL LOTHA SOCIETY}

It has been observed that the Lotha society was androcentric and men held power in all the important institutions of the society. Women were prevented from participating in social functions and ceremonies. They were considered to be lacking in rationality, and were excluded from the role of citizens. Being a patriarchal society, lineage was traced in the male line, and sons were the sole heirs to family property. According to custom the Lotha women were excluded from access to land as she would come under the protection of the man she marries. It has been stated in the Assam Census Report of 1891 that, the inferior position of Naga women as compared to men was due to the fact that they could not inherit landed property (ACR, 1891, 250). Land, to which women had closer contact through their economic activities, was not theirs.

The Lothas, like all patriarchies enforced taboos against women touching ritual objects or food and they were excluded from the ritualistic observances that occupy the foremost place in Naga culture. All ceremonies concerned with the welfare of the whole community were undertaken by the priest of the village and 
ceremonies for the general welfare of the household were performed by the master of the house. All rituals connected to agriculture was started by the priest; from the sowing to the harvesting to the eating of the first fruits after which each household followed, and that, performed by the man. It can be assumed that women's freedom in their own sphere was inhibited by patriarchal rights.

Marriages in the Lotha society were sealed by the payment of bride price to the family of the bride after fulfilment of bride service. The payment of bride price points out the economic value of the girl through which both the parties benefitted at her expense: the parents for losing her labour and the groom for gaining one. The bride, having been secured through a laborious process, the husband expected her to be under his authority and the husband claimed the right to enforce the obedience of his wife. It may be assumed that the Lotha customary law conferred full rights to the man over the woman and her labour and this can be justified by the mode of payment of the bride price. In exchange for the bride, payments were made to the bride's parents as the cost of bringing her up which included price for bride's breasts and price for intimacy with the bride. Widow remarriage was permitted amongst the Nagas and the most prevalent form of widow remarriage among the Lothas was the union of the widow with the younger brother of her deceased husband (Mills, 1980, 155). This was a marriage of convenience, for the wife having been paid for by the deceased brother was considered as belonging to the husband's family and so she became the property of the family. The Naga society in the headhunting era was generally monogamous however, tribes like the Konyak, Chang, Sema and Lotha Nagas were not averse to polygynous marriages. The Assam Census Report, 1891, records that polygyny was mostly practised by the rich Lotha men while the poor man confined to monogamy. Polygyny in the Lotha society was thus the product of men espousing multiple wives at will and also as inheritance from his deceased brother. In this way wives were accumulated, for their labour, like economic assets.

When the division of labour in the headhunting era of the Naga society is taken into consideration, it is obvious that women played the main role of engaging in life sustaining works which contributed to the economy of the tribe. On the other hand, men played the role of protector of the tribe as a consequence of which they were mainly engaged in head taking. No doubt, one motive of headhunting was to secure good crops but the constant warfare affected the economy of the people- constant raids led to loss of cattle and destruction of crops.

\section{ECONOMIC ROLE OF WOMEN}

Like in all tribal communities, Naga women played an integral role in society substantially contributing towards their economy. Women's constructive mind was bent on agriculture and other related economic activities and domesticity while men's attention and energy were chiefly on the destructive activities of headhunting and hunting for game. Woman's work of utility was more developed and practical than that of man as it sustained the society. Although women in the Lotha society did not control the means of production, they engaged in different levels of economic activities- agriculture, cotton plantation, spinning/weaving and a host of other related works. As Christine Delphy states in The Main Enemy $(1977,26)$ women's participation in the creation of goods and vital necessities is attested to by the whole ethnographic literature, and this constitutes an obstacle for ideologists who try to explain the inferior status of women by their secondary role. She goes on to state that the ethnographic documentation as a whole shows that the economic importance of the goods produced by women or by men is not related to the social pre-eminence of one or the other sex. The survival of the state was based on the strength of its economy therefore one can argue that the involvement of women folk to a large extent enhanced the successful conduct of most of these economic activities. Women of every household were engaged in production of both food crops and cash crops.

\subsection{Agriculture}

Agriculture was the main occupation of the Nagas and the Naga communities, in general, carried on the slash and burn method i.e., shifting cultivation. Land is cultivated on rotation basis, the time span depending on the fertility of the soil. Agriculture was a woman's enterprise and they did nearly 90 percent of agricultural work and worked longer hours everyday. W.W. Hunter's account of the Naga Hills highlights that women and children do the greater portion of the out-door work. All agricultural work was done without the help of a plough. The main implement of cultivation was the hoe. When not engaged in warfare, men did their part of clearing the jungle, felling trees and preparing the ground for sowing by burning it. Then it was women's work to sow the seeds and tend to the fields; to ensure a good crop was their look out. At harvest time, both men and women took part in the reaping and threshing and winnowing the paddy. Then it was carried in baskets on their backs and stored in the granary; from the granary to the home was the woman's work. After harvest and once paddy was stocked in the granary, women were not allowed to touch it till the priest had performed the ritual opening the granary for use. The first American missionary to the Nagas noted that the anarchical state of the country rendered it necessary for men to be always ready for an assault and women to cultivate the fields (BMM, 1839, 286). Men accompanied women to the fields not to work but to keep vigil. Sources reveal that there were times when a whole agricultural year had to be taken care of by women themselves. As one account holds, in the days of headhunting there were times when all able bodied men were engaged in tactical training 
for expeditions, that they neglected their share of agricultural work. At such times, the women had to undertake the share of men's work, of slashing and burning of the jungle apart from their own. And while men had bouts of resting period from hunting, women's work continued all throughout the year. Apart from paddy cultivation, they raised vegetables for domestic use and exchange. They raised food crops such as maize, millet, oatmeal, sesame seeds, soyabean, chilli pepper, yam and a variety of other crops the year round. They also engaged in cattle and pig rearing, and poultry. Through direct participation in such practices within the agricultural sector the women folk contributed to the growth of indigenous crop production process. However, women's prominence in agriculture did not necessarily endow them with economic or political influence.

\subsection{Cotton Plantation}

Next to agriculture women engaged in cotton plantation on a large scale. Though men rendered their services in agriculture cotton plantation was an occupation left entirely to women. Cotton was important not only because it clothed the entire family but because of its economic value. For centuries women have farmed cotton and indigo, spun, woven and dyed cotton textiles. The entire process of cultivation, picking, deseeding and turning it into balls of yarn was done by women. All activities associated with cotton were done with the simplest and crudest of implements. Cleaning of the cotton was done by means of a flat stone and a small rod about 6 inches long. The stone was placed on the ground and a handful of raw cotton was placed on it and the rod was rolled over it with pressure to separate the seeds from the fibre. The spinning wheel was practically unknown to the Nagas and the primitive method of spinning thread on the naked thigh was universally practised. The contribution of women to the economy of the Lothas through cotton plantation is supported by colonial sources. The Lothas traded cotton not only to the plains but to the neighbouring tribes as well. Captain Brodie, stated in 1844 that raw cotton was brought down by the westerly dwars, particularly by the Lotha tribe (Brodie, 1844). The Census of 1891 mentions that large trade in cotton was carried out with the Marwari traders of Golaghat, a great deal of which was taken down the Doyang (Wokha district) by boat in the cold season (1891, 248). They also exported to the Angami Nagas who lived at a high elevation with little success in cotton cultivation and had to import whatever material they used from the Rengma and Lotha tribes (Samman, 1897, 16). In 1903-04, it was estimated that about 4,500 maunds of cotton were exported to Golaghat (Allen, 1905, 45). In exchange for cotton they brought back other articles of use and consumption. Taking into account the huge amount of cotton traded by the Lotha Nagas, it can be assumed that women's contribution to the economy of the tribe was significant.

\subsection{Cottage Industry}

Besides, women also had to their credit household industries like pottery, spinning and weaving which was handed on from mother to child by example and precept. A notable industrial engagement characteristic of pre-colonial economy was weaving. It was an industry that engaged the services of the women population in such aspects as cotton picking, ginning, processing, spinning etc. Cotton prepared by women with the crudest of implements was spun and woven into cloths, on primitive looms, for the entire family. If weaving was an industry which had no buyers outside their hills it was a very useful industry for the Nagas who depended on their own products. Dyeing of cloths was done by women; indigo was abundantly used. Potmaking, as in all primitive societies, a profession of great utility was left to the women. Women skilfully searched for areas where the proper layers of clay were exposed and quarried out the raw material. The entire process from quarrying, carrying, washing, mixing, moulding, modelling and shaping to firing was done by women and with bare hands without the help of a wheel. Potmaking was a trade which was not undertaken by all Lotha villages therefore it was a thriving industry in some villages. Food preservation was another engagement of women. After the harvest, women busied themselves with food preservation- drying edible leaves and stalks of plants, chilli peppers and tapioca. Women were also responsible for collecting fuel- firewood and water. There is, therefore, no doubt that the major share of work of economic value was done by women.

\section{POLYGYNY AND WOMEN}

The social and economic organization of the Lotha Nagas was such that it exploited the labor and sexuality of women, through the practice of polygyny and levirate. Women were the producers and reproducers with no field of their own. In a society like that of the Lotha Nagas where women are the primary agricultural workers polygyny seemed to have been valued and men married many wives. The labour of women was of great economic importance that it did not deter men from paying bride price and acquiring additional wives.

The factors that drove Lotha men into polygynous marriages can be analysed in the light of studies conducted on polygynous marriages in agricultural societies. In the Lotha society, the main motive for espousing additional wives generally arose out of the first wife's inability to give heirs. In order to satisfy his longing for progeny and being conditioned by patriarchal values Lotha wives succumbed to the wants of men. However, it was not purely the craving for heirs, for man who already had a number of heirs took multiple wives on the pretext of relieving his wife of her burden. According to source, this, however, was a mere excuse for his desire for more wealth. Whatever may have been the reason for espousing multiple wives, men must 
have discovered the gains it brought in the economic front. Wealth, in the pre-colonial societies, was assessed in terms of paddy- the number of fields and the number of granaries one possessed. With greater number of wives and children to work the fields, man could get more food with free labour. As Boserup states an additional wife is an additional economic asset which helps the family to expand its production (Boserup, 1970, 37). Men took multiple wives and fathered a number of children, who, in effect, became his labourers tending to his fields, generating his wealth. Taking the statement of Boserup, multiple wives was advantageous particularly where the main crop was cotton, since women and children were of great help in the plucking season (Boserup, 1970, 47). In polygynous marriages, women's productive and reproductive labour was exploited. The control of reproduction, which is both the cause and the means of the other great material oppression of women -- sexual exploitation - constitutes the second facet of the oppression of women (Delphy, 1977, 38). A man with more number of wives and children could expand his cultivation to around four to five fields and become more and more prosperous, with about twenty granaries, when a poor man could barely manage one field. Hence, as Boserup states, the institution of polygamy is a significant element in the process of economic development (Boserup, 1970, 38).

The other reason for polygynous marriage was that a man's status in society and in the village was determined by the number of wives he had. It was a proof of his ability to be able to feed many women when a poor man could not afford to feed even one wife. Therefore, the larger the number of wives the greater was his influence in the society. Through the labours of his wives, he became prosperous and became a lavish entertainer. In this way polygyny became a badge of distinction for the man at the expense of the wives. Polygyny thus was practised by the rich Lotha men; rich men created by women's labour. The wife's labour enabled him to procure a second wife and so on, and wives multiplied. Polygyny in the Lotha society was indeed a system of marriage which used women's labour for the economic advancement of the husband. A woman who became the second wife of a man in the late 1940s states that just like her, the earlier generation of women in such marriages, were economic assets for the husbands. They were made to tend to a number of paddy fields, cotton plantation and other work of economic value because of the husband's desire to accumulate more wealth.

Boserup states that a woman marrying a man who already has a number of wives often joins the household more or less in the capacity of a servant for the first wife (Boserup, 1970, 43). This practise is to be found in the Lotha marriages- the eldest wife occupied a position of some authority in the household though she had no special rights. It was she who took charge of work distribution among the younger wives. She stayed home taking charge of the little ones and detailed the younger wives to the field, to collect firewood, water and brew beer. In Jack Goody's study in Ghana it was found that among the rich men, two wives were exempted from labour, the chief wife who looked after the household and another who was consecrated to his god. The others were obliged to till the ground and plant millet and yams, 'whilst the man only idly spends his time in impertinent tattling and drinking of palm-wine (Goody, 1973, 175). Similarly, the Lotha husband almost lived a life of rest enjoying the fruits of labour of the wives and children. Though the man accompanied the wives to the fields as an overseer and would spend his time sipping on rice beer and doing menial works in the field shack.

In addition to their chores, the husband having become a lavish entertainer, women were compelled to brew rice beer endlessly for the husband's guests. They were to serve but they were not to sit with the men and take part in discussion or even listen to their conversation. It was the man of the house who wielded absolute control over the household. Disobedience to the man of the house was followed by punishment. Reference can be made here of how a man punished the members of the household from the eldest wife to the youngest child by spanking them for having failed to meet him halfway to carry his load, on his return from a trading trip to Assam. Walby states that it is through patriarchal production relations that women's household labour is expropriated by their husbands or cohabitees; that housewives are the producing class, while husbands are the expropriating class (Walby, 1990, 21). While husbands claimed the produce by virtue of being the owners of land, the ceaseless labour of women towards production brought her no reward. She had no claim over her own produce for it was not her land. Trade in the rural economy was done through barter. When money economy was introduced during colonial rule the benefits of trade did not fall into the hands of women. This made her a dependent even though it was her labour which defined the economic status of the husband and consequently the advancement of the tribe.

\section{CONCLUSION}

Narratives to information about men with more than one wife, usually starts with, "he was a rich man", "he had two wives" and "he had twenty granaries" or to that effect. Proverbially though, men were engaged in 
headhunting all their lives when then, could they have laboured to stock riches in their granaries! It is only sensible to state that it was the labour of the woman that contributed to his riches. Can this, then, mean that women were treated like commodities or assets? Women were indeed accumulated like commodities, and therefore, were economic assets for their labours brought gains to husbands. This is justified in that Lotha men rarely divorced their wives; even barren women were not divorced- she having been paid for with bride price. Considering that production and reproduction are the main determining factors for any culture to progress, and taking into account the amount of labour women put into for the economic enhancement of the husbands and the advancement of the tribe, it could have earned her a place in the society but this was not so. Because of patriarchy, as is held by Stetson, "the economic status of the human race in any nation, at any time, is governed mainly by the activities of the male: the female obtains her share in the racial advance only through him" (Stetson, 1900, 9). Therefore, despite the substantial contribution to the growth of economy women's share in the racial advance was only through men by the fact that men owned the lands. Tradition and customs of the society which was androcentric constrained the recognition of women's participation in the progress of society. It is to be noted that the sexual division of labour- men's role of fighting and hunting and women's role of producing and reproducing- was based on equitable division. Yet, the work of men, destructive as it was, was considered to be more fitfully accomplished than that of women. Colonial writings often depict Naga women as engaged in works associated with drudgery. In other words, they considered the manual work of women as menial work. But it was this menial work of women that had, for centuries sustained the lives of the population. However economically active and productive women may have been they were not able to claim the proceeds of their labour or have it formally accounted for. The importance of headhunting warfare, the centralization of socio-religious and political activities in the hands of men and the processes of production and reproduction in kinship networks subordinated women to men. The paper concludes that the work of 'drudgery' women did was, in the long run, a positive force behind the survival and propagation of the tribe. Women, therefore, deserve to be written back into history.

\section{REFERENCES}

[1] Nagaland State Human Development Report, Government of Nagaland, Kohima, 2004

[2] Wokha District Human Development Report, Government of Nagaland, Kohima, 2013

[3] J.P. Mills, The Lotha Nagas, (1922) Government of Nagaland, Kohima, 1980

[4] G.M. Godden, Naga and Other Frontier Tribes of North East India, Journal of the Anthropologicl Institute, Vol. 26, 1897, pp.161-201

[5] J.P. Mills,. The Effect of Ritual upon Industries and Arts in the Naga Hills, Man, Sept., Nos. 143-144, 1935

[6] J.P. Mills, The Lotha Nagas, (1922) Government of Nagaland, Kohima, 1980

[7] Ezamo Murry, The Introduction and the Growth of Christianity in Kyong area of Nagaland, Assam Printing Works, Jorhat, Assam, 2003

[8] Assam Census Report, 1891

[9] J.P. Mills, The Lotha Nagas, (1922) Government of Nagaland, Kohima, 1980

[10] Assam Census Report, 1891, Vol. I, Assam Report, E.A. Gait

[11] Christine Delphy, The Main Enemy, Women's Research and Resources Centre, London, 1977, https://libcom.org/files/delphymainenemy.pdf accessed 5th May 2015

[12] W.W. Hunter, A Statistical Account of Assam, Vol. II, Trübner \& Co., London, 1879

[13] Miles Bronson's Journal in Baptist Missionary Magazine, Vol. XIX, 1839

[14] Capt. Brodie, Hill Tracts Between Assam and Burma, 1844 in Selection of Letters, (1873, 1909) Vivek Publishing Company, Delhi, 1978

[15] Census of India, 1891, Vol. I, Assam Report, E.A. Gait

[16] H. F. Samman, Monograph on Cotton Fabrics of Assam, Office of the Superintendent of Government Printing, Calcutta, Calcutta, 1897

[17] B.C. Allen, Naga Hills and Manipur, Baptist Mission Press, Calcutta, 1905

[18] Ester Boserup, Woman's Role in Economic Development, George Allen \& Unwin Ltd., London, 1970Ibid

[19] Christine Delphy, The Main Enemy, Women's Research and Resources Centre, London, 1977, https://libcom.org/files/delphymainenemy.pdf accessed 5th May 2015

[20] Ester Boserup, Woman's Role in Economic Development, George Allen \& Unwin Ltd., London, 1970Ibid

[21] Jack Goody, ed., The Character of Kinship, Cambridge University Press, Cambridge, 1973

[22] Sylvia Walby, Theorizing Patriarchy, Basil Blackwell Ltd., Oxford, UK, 1990

[23] Charlotte Perkins Stetson, Women and Economics, Small, Maynard \& Company, Boston, 1900 